\title{
Le monde antique rural dans l'est lyonnais (Rhône et Isère)
}

Projet collectif de recherche (2012)

\section{Catherine Coquidé}

\section{(2) OpenEdition \\ Journals}

Édition électronique

URL : https://journals.openedition.org/adlfi/15011

ISSN : 2114-0502

\section{Éditeur}

Ministère de la Culture

\section{Référence électronique}

Catherine Coquidé, « Le monde antique rural dans l'est lyonnais (Rhône et Isère) » [notice

archéologique], ADLFI. Archéologie de la France - Informations [En ligne], Auvergne-Rhône-Alpes, mis en ligne le 16 juillet 2015, consulté le 29 juillet 2021. URL : http://journals.openedition.org/adlfi/15011

Ce document a été généré automatiquement le 29 juillet 2021.

(C) ministère de la Culture et de la Communication, CNRS 


\section{Le monde antique rural dans l'est lyonnais (Rhône et Isère)}

Projet collectif de recherche (2012)

\section{Catherine Coquidé}

\section{NOTE DE L'ÉDITEUR}

Organisme porteur de l'opération : Inrap

1 Le PCR « Monde Antique Rural » dans l'est lyonnais souhaite exploiter l'ensemble des données antiques issues du terrain (diagnostics, fouilles et prospections récentes). Le propos intègre également les «vides d'occupation » en prenant en compte l'ensemble des emprises étudiées, notamment celles n'ayant livré aucune trace de présence galloromaine. Les données, intégrées au sein de deux bases de données («Opération » et «Occupation»), seront en outre projetées sur divers fonds cartographiques et interrogées (SIG).

2 La seconde année a permis de finaliser et de renseigner la BD « Opération » (sondages et fouilles) et de dessiner les bases de la BD «Occupation ». Divers fonds cartographiques sont en cours de finalisation et permettent d'accéder à un état de la recherche des origines à fin 2011 (surfaces étudiées, résultats en terme de présence/ absence, choix topographique, hydrographie...). La modélisation des données de prospections est en cours et bénéficie du renfort d'O. Andru (Ass. Histoire et d'Archéologie de SRJ).

3 Pour 2014, l'équipe demande le renouvellement du PCR et joint deux demandes de datation Artemis (rubriques intégrées à la base le 2 septembre) concernant la datation de deux larges fossés équidistants d'environ $700 \mathrm{~m}$ et en cours de comblement, une opportunité rare dans un secteur où la question des centuriations, ou de larges parcellaires, est toujours d'actualité. 


\section{INDEX}

lieux https://ark.frantiq.fr/ark:/26678/pcrtSEeAipsBlD, https://ark.frantiq.fr/ark:/26678/ crtB8WDyqd6u9, https://ark.frantiq.fr/ark:/26678/pcrtdGSf7FYRvz, https://ark.frantiq.fr/ark:/ 26678/pcrtjNthkbl8NF

chronologie https://ark.frantiq.fr/ark:/26678/pcrtxT02uJOogm, https://ark.frantiq.fr/ark:/ 26678/pcrtof7EHNsS2e, https://ark.frantiq.fr/ark:/26678/pcrtZTmusVUU24

nature https://ark.frantiq.fr/ark:/26678/crtqI2kNablQH

Année de l'opération : 2012

sujets https://ark.frantiq.fr/ark:/26678/pcrtLf3Bt5nKRt, https://ark.frantiq.fr/ark:/26678/ crt5AOuUmbGVy, https://ark.frantiq.fr/ark:/26678/pcrtc6LNXVNfT8, https://ark.frantiq.fr/ ark:/26678/pcrtJtBUSJRN9p, https://ark.frantiq.fr/ark:/26678/pcrt3G8RooGUeu

\section{AUTEURS}

\section{CATHERINE COQUIDÉ}

Inrap 